\title{
Proceeding
}

Supplementary Issue: Spring Conferences of Sports Science. Costa Blanca Sports Science Events, 14-15 June 2019. Alicante, Spain.

\section{Study on the enabling capacity in the individual roles of basic competitive volleyball}

\author{
MATTEO AQUINO ${ }^{1} \square$, FRANCESCA MARRA ${ }^{1}$, GAETANO ALTAVILLA² \\ 1 University of Salerno, Italy \\ 2University of Split, Croatia
}

\begin{abstract}
Testing is used to measure the performance and, therefore, to check for the improvements resulting from training activity. More and more frequently, coaches require checks even during the current sporting season to measure the state of the athletes' performance and possibly change their training plans in order to make them more effective. Increasingly testing also has a monitoring function and, therefore, it is expected in the ordinary training activities without changing the annual planning. To do this, it is necessary to provide a type of functional tests for training. The purpose of this study is to monitor the state of efficacy of individual volleyball fundamental of a basic competitive level. Keywords: Enable capacity; Competitive basic volleyball; Tests; Monitoring and evaluation system.
\end{abstract}

\section{Cite this article as:}

Aquino, M., Marra, F., \& Altavilla, G. (2019). Study on the enabling capacity in the individual roles of basic competitive volleyball. Journal of Human Sport and Exercise, 14(4proc), S1046-S1057. doi:https://doi.org/10.14198//hse.2019.14.Proc4.67

Corresponding author. University of Salerno, Italy.

E-mail: matteoaquino35@gmail.com

Supplementary Issue: Spring Conferences of Sports Science. Costa Blanca Sports Science Events, 14-15 June 2019. Alicante, Spain.

JOURNAL OF HUMAN SPORT \& EXERCISE ISSN 1988-5202

(c) Faculty of Education. University of Alicante

doi:10.14198/jhse.2019.14.Proc4.67

S1046 | 2019| Proc4 | VOLUME 14

C 2019 University of Alicante 


\section{INTRODUCTION}

The basic competitive male volleyball is that part of the volleyball that includes all the volleyball categories ranging from youth championships to the $C$ series championships (D'Isanto et al, 2019). In the basic competitive men's volleyball there is no monitoring system, with the characteristics shown there, concerning training activities and the collection of qualitative and quantitative information. (Di Tore et al, 2018). Do not forget that a monitoring process can be expected at any age, both on males and females (Parisi \& Raiola, 2014, Raiola, Di Tore, 2012ab). All types of analysis can be used to support this monitoring system, such as video analysis (Raiola et al, 2013; Izzo et al, 2018). In essence, the evaluation of sports performance is fundamental at every level, in its theoretical aspects (D'Isanto et al, 2017) and its practical indications (D'lsanto et al, 2019). What is proposed in this article is a monitoring system for training activities (Alminni et al, 2019a) in the context of basic competitive men's volleyball. Monitoring means the application of a system which, based on the use of specific and appropriate criteria, aims to control the duration of a training or a whole competition (Alminni et al, 2019b) season in a structured manner and with recurrent step (Altavilla \& Raiola, 2018), for the purposes of:

- Highlight the trend, starting from elementary variables of the observed phenomenon;

- Record the deviations between what is taking place and what was expected;

- Inform the players of the monitoring system (recipients, beneficiaries, users, controllers) about the critical issues that arise from time to time to search for the most appropriate solutions.

By monitoring we therefore mean preparation of an information gathering system:

- Coded;

- Registered;

- Constantly updatable.

The monitoring system therefore constitutes the essential support to the evaluation process (Raiola \& D'lanto, 2016) on the athlete, the team and the workout methodology used by the coach or coaches (D'Elia et al, 2019, Raiola, 2014). So thanks to data collected by this monitoring system, we can evaluate our training activities and the athletes. This type of system is being proposed because in medium and low competitive level men's volleyball, scientific instruments and simple fruition about the objective monitoring of training actions and their effectiveness are lacking (Forte et al, 2019ab). Testing is used to measure the performance and, therefore, to verify the resulting improvements to training activity (Forte et al, 2019). More and more frequently, coaches require checks even during the current sportive season to measure the state of the athletes' performance (Federici et al, 2019, Invernizzi et al, 2019) and possibly change their training plans in order to make them more effective. Increasingly testing has also a monitoring function and, therefore, is expected in the ordinary training activities without changing the annual planning. To do this, it is necessary to provide a type of functional tests for training.

The aim is to identify a monitoring system consisting of tests, which present a qualitative and quantitative numerical detection system. It intends to look for a monitoring system consisting of tests, which have a quali/quantitative numerical detection system. The tools, from which these numerical values of the tests derive, are compatible with the training activities as they don't influence the ordinary activities. The goal is to constantly code, record and update training activities. Furthermore, there will be a quantification of the training activities of each individual athlete, so that the coach can decide game to game which players are most 
effective at that time. In this way, each individual athlete will be stimulated to give the maximum of his possibilities every workout in order to be included in the initial roster.

\section{METHOD}

The method is experimental and longitudinal and it consists in detecting the initial and final data in a period of time of 6 months for the technical skills of receiving Bagher, set and spike in a natural sample of 12 athletes, aged from 18 to 30 years, because it is a whole team of first division championship.

The tests used are the following:

- Receiving Bagher test;

- Stroking test in an area previously determined by the examiner;

- $\quad$ Setting test in place 4 and in place 2;

- Spiking test of side- and middle-hitters players.

We reach the data collection goal of the monitoring system with specific indicators for each fundamental; the indicators will be given quantitative value thanks to the tools used. Moreover, the methods of detection will also be described below:

1) Fundamental of spike:

- Indicator: Accuracy of the spike.

- Detection Tool: Structured sheet with table 1: The table contains the names of the attackers on the left and these two phrases at the top: "spike +" and "spike -".

- Modality: At every player will be recorded 10 attacks and whether these are well directed toward the area you want to examine. In particular: "aspike +" shall mean the spike that goes in the area indicated by the coach; "spike -" shall mean all the outside-area spike, in the net or off the field.

NB: In this test should not be the fundamental of the block; furthermore, the attacks should not be consecutive, always alternating the attackers so as to simulate as much as possible the race situation and so as not to adversely affect the objectivity of detection because of physical fatigue.

2) Fundamentals of service, Bagher receiving and set: According to this monitoring system, these fundamentals should be analysed together. However, to do this, we need a second coach or an injured athlete who can help in the surveys or at least a good knowledge of the sport to help with the measurements:

- Indicators: Accuracy and effectiveness of the service, of the receiving Bagher and of the set.

- Detection Tool: Structured sheet with 3 tables:

1. A service table, in the upper left of the sheet.

In this table, in the first column on the left we write only the name of the players and in the top-header of this table we write the words "service in the area", "ace in the area", "directed service mistake".

2. On the same horizontal line of the previous table, we create another table: the receiving table; in its first column on the left we write the names only of the receptors in the header and the words: "receiving +", "receiving -", "receiving mistake".

3. Finally, we insert the last table: the set table, below the previous ones. In the first column on the left of this table, we write only the names of the setters and we write in the top-header: "set ++", "set +", "set -". 
Advice: create two tables if you want to analyse sets is in place 4 and in place 2 . The method is the same: just specify, through the title of the table, whether the set is evaluated in zone 4 or into zone 2.

- Modality:

\section{Of service:}

For each player, 10 services will be evaluated.

Each service in the area indicated by the examiner, but not ace, will go to the cell "service in the area".

Each service in the area, that is ace, will go to the cell "ace in the area".

Each service that will not go into the area indicated by the coach, service in the net or service out of the field, will go to the cell " directed service mistake".

2. Of receiving:

For each player, 10 receptions will be evaluated.

Each reception, sufficiently high that comes in 3-meters-line, will go into the cell: "receiving +".

Every reception that will go out of 3-meters-line or will be too low to be set or if the player gets an ace, will go into the cell "receiving -".

3. Of set:

For each setter, 10 sets will be evaluated in the area 4 and 10 sets will be evaluated in the area 2 (for a total of 20 sets).

Each set, technically perfect and precise to the zone, will go in the cell "set ++".

Each set, attachable by the attacker but not technically perfect and not very precise, will go in the cell "set + ".

Each set, that can't be attacked by the attacker or foul, will go in the cell "set -".

\section{RESULTS}

The percentage results are:

\section{- $\quad$ Receiving Bagher test:}

November:

- The percentage of "reception +" by 4-places-players and libero-players is $34 \%$.

January:

- The percentage of "reception +" by 4-places-players and libero-players is $48 \%$.

March:

- The percentage of "reception +" by 4-places-players and libero-players of $56 \%$.

\section{- $\quad$ Stroking test in an area previously determined by the examiner:}

November:

- The percentage of "service in the area with or without ace" of the whole team (with the exception of the libero-players) is $60 \%$.

January:

- The percentage of "service in the area with or without ace" of the whole team (with the exception of the libero-players) is $68 \%$.

March:

- The percentage of "service in the area with or without ace" of the whole team (with the exception of the libero-players) is $69 \%$. 


\section{- $\quad$ Setting test in place 4 and in place 2:}

November:

- The percentage of positive sets in place 4 by the setters is $95 \%$.

- The percentage of positive sets in place 2 by the setters is $90 \%$. January:

- The percentage of positive sets in place 4 by the setters is $95 \%$.

- The percentage of positive sets in place 2 by the setters is $90 \%$.

March:

- The percentage of positive sets in place 4 by the setters is $90 \%$.

- The percentage of positive sets in place 2 by the setters is $95 \%$

\section{- $\quad$ Spiking test of side- and middle-hitters players:}

November:

- The percentage of "spike + " of the middle-blocker-players is $80 \%$.

- The percentage of "spike + " of opposite-spikers is of $53.3 \%$.

- The percentage of "spike + " of wing-spikers is $36,6 \%$.

January:

- The percentage of "spike + " of the middle-blocker-players is $80 \%$.

- The percentage of "spike + " of opposite-spikers is of $53.3 \%$.

- The percentage of "spike +" of wing-spikers is of $53.3 \%$.

March:

- The percentage of "spike + " of the middle-blocker-players is $80 \%$.

- The percentage of "spike + " of opposite-spikers is of $46.6 \%$.

- The percentage of "spike + " of wing-spikers is of $53.3 \%$.

The testing monitoring function can be considered implemented. Refinement of the tests are needed.

\section{Layout table for the test with the results}

\section{1) Receiving Bagher tests:}

Table 1. November

\begin{tabular}{|l|c|c|c|}
\hline First name & Bagher receiving + & Bagher receiving - & Bagher receiving mistake \\
\hline Alessandro & 2 & 7 & 1 \\
\hline Andrea & 5 & 4 & 1 \\
\hline Enrico & 3 & 5 & 2 \\
\hline Luca & 5 & 4 & 1 \\
\hline Generoso Giuseppe & 2 & 5 & 3 \\
\hline
\end{tabular}

Table 2. January

\begin{tabular}{|l|c|c|c|}
\hline First name & Bagher receiving + & Bagher receiving - & Bagher receiving mistake \\
\hline Alessandro & 3 & 6 & 1 \\
\hline Andrea & 7 & 2 & 1 \\
\hline Enrico & 5 & 3 & 2 \\
\hline Luca & 6 & 2 & 2 \\
\hline Generoso Giuseppe & 3 & 5 & 2 \\
\hline
\end{tabular}


Table 3. March

\begin{tabular}{|l|c|c|c|}
\hline First name & Bagher receiving + & Bagher receiving - & Bagher receiving mistake \\
\hline Alessandro & 5 & 2 & 3 \\
\hline Andrea & 7 & 2 & 1 \\
\hline Enrico & 6 & 2 & 2 \\
\hline Luca & 7 & 2 & 1 \\
\hline Generoso Giuseppe & 3 & 5 & 2 \\
\hline
\end{tabular}

2) Stroking test in an area previously determined by the examiner:

Table 4. November

\begin{tabular}{|l|c|c|c|}
\hline First name & Service in the area & Ace in the area & Directed service mistake \\
\hline Andrea & 4 & 1 & 5 \\
\hline Matteo & 8 & 2 & 1 \\
\hline Carmine & 6 & 0 & 4 \\
\hline Luca & 5 & 1 & 4 \\
\hline Giovanni Francesco Pio & 2 & 0 & 8 \\
\hline Carmine & 5 & 0 & 5 \\
\hline Elio & 7 & 2 & 1 \\
\hline Matteo & 6 & 2 & 2 \\
\hline Antonio & 6 & 1 & 3 \\
\hline Generoso Giuseppe & 2 & 0 & 8 \\
\hline
\end{tabular}

Table 5. March

\begin{tabular}{|l|c|c|c|}
\hline First name & Service in the area & Ace in the area & Directed service mistake \\
\hline Andrea & 6 & 2 & 2 \\
\hline Matteo & 8 & 2 & 0 \\
\hline Carmine & 6 & 0 & 4 \\
\hline Luca & 5 & 3 & 2 \\
\hline Giovanni Francesco Pio & 3 & 1 & 7 \\
\hline Carmine & 5 & 2 & 3 \\
\hline Elio & 6 & 2 & 2 \\
\hline Matteo & 6 & 2 & 2 \\
\hline Antonio & 6 & 1 & 3 \\
\hline Generoso Giuseppe & 3 & 1 & 6 \\
\hline
\end{tabular}


Table 6. Stroking test (service in the area). Significance level was set at $p<0.05$

T-Test pre and post (November-March)

\begin{tabular}{|c|l|l|l|l|l|l|l|l|}
\hline & \multicolumn{4}{|l|}{ Coupled differences } & & & Sign. \\
\cline { 2 - 5 } & Average & $\begin{array}{l}\text { Std } \\
\text { Deviation }\end{array}$ & $\begin{array}{l}\text { Average } \\
\text { standard } \\
\text { error }\end{array}$ & $\begin{array}{l}\text { Confidence interval of 95\% } \\
\text { difference }\end{array}$ & lower & Higher & gl & $\begin{array}{l}\text { (Two- } \\
\text { tailed) }\end{array}$ \\
\hline VAR01 & -.30000 & .82327 & .26034 & -.88893 & .28893 & -1.152 & 9 & .279 \\
\hline
\end{tabular}

Table 6 shows that there isn't a significant difference between the period from November to March $(p=0.279)$. Therefore there isn't a significant improvement.

Table 7. Stroking test (Ace in the area). Significance level was set at $p<0.05$

T-Test pre and post (November-March)

\begin{tabular}{|l|l|l|l|l|l|l|l|l|}
\hline & \multicolumn{3}{|l|}{ Coupled differences } & & & Sign. \\
\cline { 2 - 5 } & Average & $\begin{array}{l}\text { Std } \\
\text { Deviation }\end{array}$ & $\begin{array}{l}\text { Average } \\
\text { standard } \\
\text { error }\end{array}$ & $\begin{array}{l}\text { Confidence interval of 95\% } \\
\text { difference }\end{array}$ & lower & higher & gl & $\begin{array}{l}\text { (Two- } \\
\text { tailed) }\end{array}$ \\
\hline VAR04 & -.70000 & .82327 & .26034 & -1.28893 & -.11107 & -2.689 & 9 & .025 \\
\hline
\end{tabular}

Table 8. Stroking test (Directed service mistake). Significance level was set at $p<0.05$

T-Test pre and post (November-March)

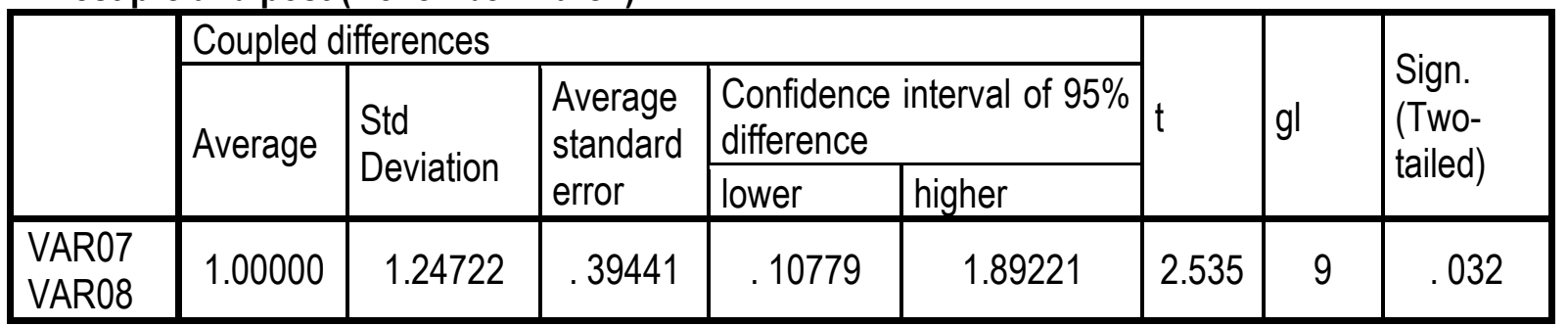

Tables 7 and 8 show significant differences $(p=0.025$ and $p=0.032)$, so there was a significant improvement in the period between November and March.

\section{3) Setting test in place 4 and in place 2:}

Table 9. November

\begin{tabular}{|l|c|c|c|}
\hline & Place 4 & Set + & Set - \\
\hline First name & Set ++ & 2 & 1 \\
\hline Elio & 8 & 6 & Set - \\
\hline Matteo & 3 & \multicolumn{2}{|l|}{} \\
\hline & Place 2 & Set + & 2 \\
\hline First name & Set ++ & 3 & 1 \\
\hline Elio & 5 & 6 & \\
\hline Matteo & 4 & & \\
\hline
\end{tabular}


Table 10. January

\begin{tabular}{|l|c|c|c|}
\hline & Place 4 & Set + & Set - \\
\hline First name & Set ++ & 3 & 1 \\
\hline Elio & 7 & 6 & Set - \\
\hline Matteo & 3 & \multicolumn{2}{|l|}{} \\
\hline & Place 2 & Set + & 1 \\
\hline First name & Set ++ & 6 & 1 \\
\hline Elio & 3 & 6 & \\
\hline Matteo & 3 & & \\
\hline
\end{tabular}

Table 11. March

\begin{tabular}{|l|c|c|c|}
\hline & Place 4 & Set + & Set - \\
\hline First name & Set ++ & 1 & 1 \\
\hline Elio & 8 & 5 & 1 \\
\hline Matteo & 4 & \multicolumn{2}{|l|}{} \\
\hline & Place 2 & Set + & Set - \\
\hline First name & Set ++ & 7 & 1 \\
\hline Elio & 3 & 6 & \\
\hline Matteo & 3 & & \\
\hline
\end{tabular}

4) Spiking test of side- and middle-hitters players:

Table 12. November

Middle-Hitters players Spike Test

\begin{tabular}{|l|c|c|}
\hline First name & Spike + & Spike - \\
\hline Matteo & 8 & 2 \\
\hline Giovanni Francesco Pio & 8 & 2 \\
\hline
\end{tabular}

\section{Opposite-spikers Spike Test}

First name

Carmine

Carmine

Antonio

Spike +
5
5
6

Spike -

5

5

4

\section{Wing-spikers Spike Test}

First name

Andrew

Luca

Generoso Giuseppe

\begin{tabular}{|c|c|}
\hline Attack + & Attack - \\
\hline 6 & 4 \\
\hline 3 & 7 \\
\hline 2 & 8 \\
\hline
\end{tabular}

Attack - 
Table 13. January

Middle-Hitters players Spike Test

\begin{tabular}{|l|c|c|}
\hline First name & Spike + & Spike - \\
\hline Matteo & 8 & 2 \\
\hline Giovanni Francesco Pio & 8 & 2 \\
\hline
\end{tabular}

\section{Opposite-spikers Spike Test}

\begin{tabular}{|l|c|c|}
\hline First name & Spike + & Spike - \\
\hline Carmine & 5 & 5 \\
\hline Carmine & 5 & 5 \\
\hline Antonio & 6 & 4 \\
\hline
\end{tabular}

\section{Wing-spikers Spike Test}

\begin{tabular}{|l|c|c|}
\hline First name & Spike + & Spike - \\
\hline Andrea & 7 & 3 \\
\hline Luca & 6 & 4 \\
\hline Generoso Giuseppe & 3 & 7 \\
\hline
\end{tabular}

Table 14. March

Middle-Hitters players Spike Test

First name

Matteo

Giovanni Francesco Pio

\begin{tabular}{|c|c|}
\hline Spike + & Spike - \\
\hline 8 & 2 \\
\hline 8 & 2 \\
\hline
\end{tabular}

\section{Opposite-spikers Spike Test}

First name

Carmine

Carmine

Antonio

\begin{tabular}{|c|c|}
\hline Spike + & Spike - \\
\hline 5 & 5 \\
\hline 3 & 7 \\
\hline 6 & 4 \\
\hline
\end{tabular}

\section{Wing-spikers Spike Test}

First name

Andrea

Luca

Generoso Giuseppe

Spike +
7
6
3

Spike -

3

4

8




\section{Results of the tests:}

1) Result of receiving Bagher tests:

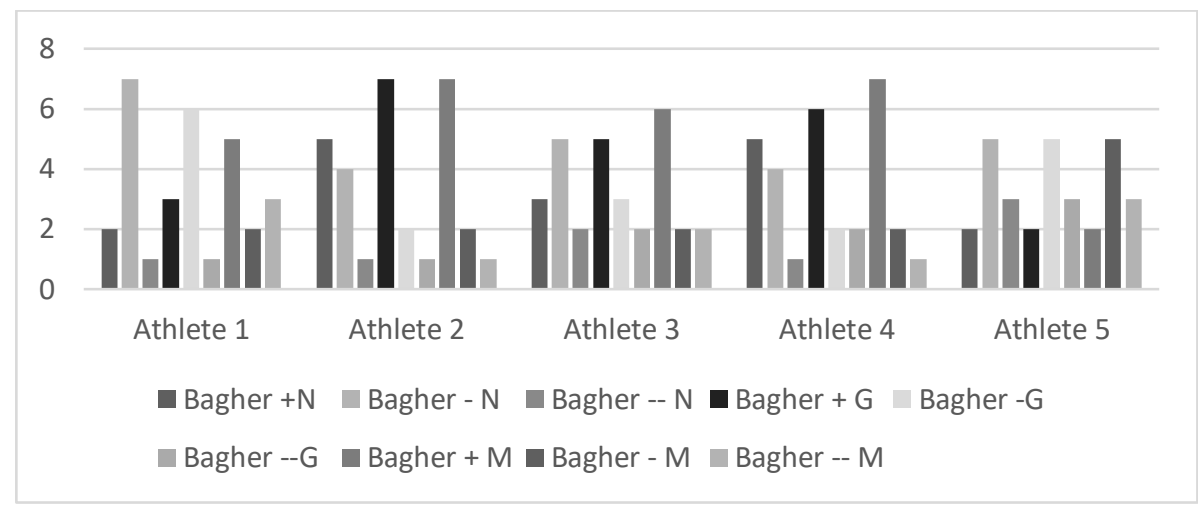

Figure 1. Receiving Bagher Test.

2) Result of stroking tests in an area previously determined by the examiner:

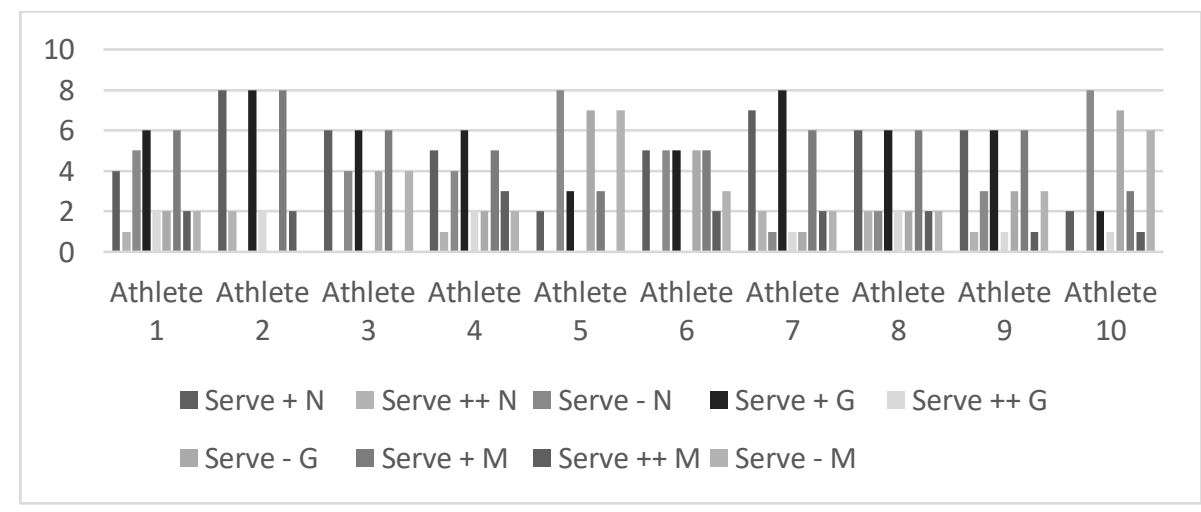

Figure 2. Stroking Test.

3) Result of setting test in place 4 and in place 2:

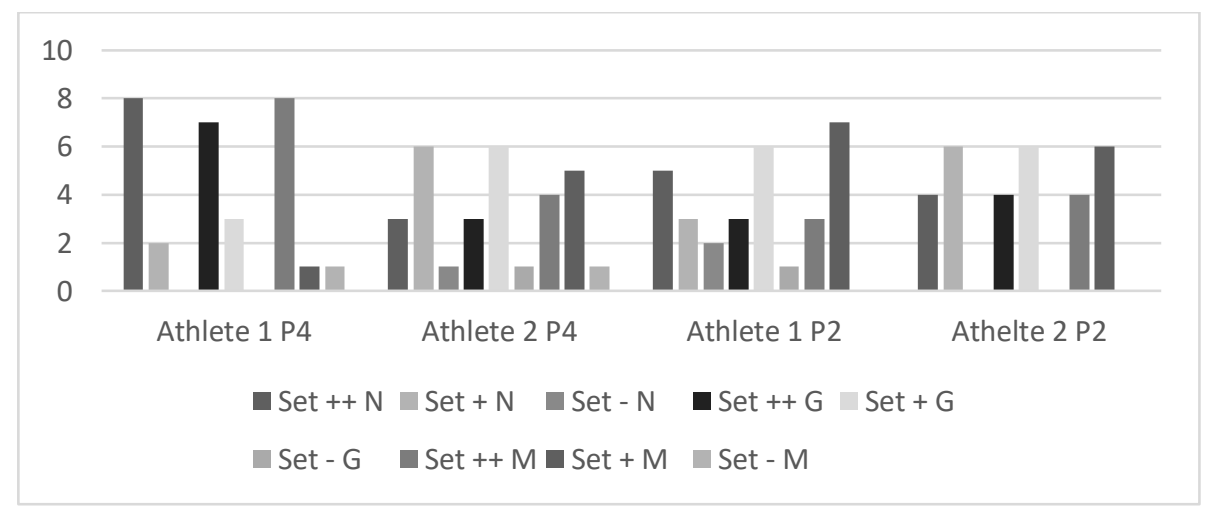

Figure 3. Setting Test. 
4) Result of spiking test of side- and middle- hitters players:

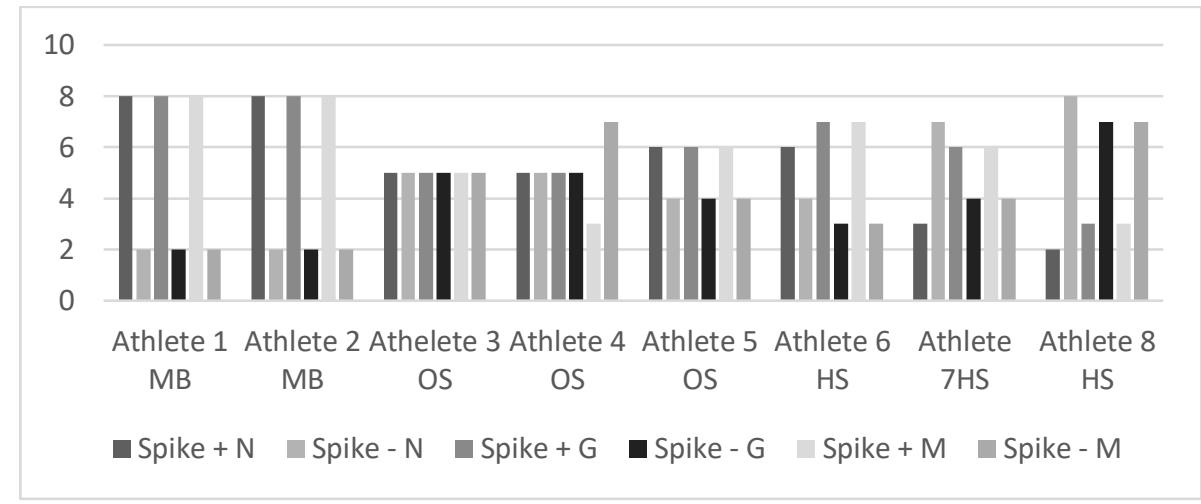

Figure 4. Spiking Test

The tests results were graphically represented by the histograms so as to be able to enclose in a small space the representation of a test season.

\section{DISCUSSION}

With these simple tables we managed to build a system for monitoring the progress of training activities in an entire season. The surveys took place every two months. Each of detections cycle we went to check which fundamentals were increased and which not. The players appeared very excited about the new monitoring system. These tests have supported the technical and tactical evaluation and intrinsic motivation of the boys to be examined.

\section{CONCLUSION}

From the results it turns out that the training activities were constantly monitored and, therefore, the purpose can be considered achieved because the coach has occurred over time the level of athletes' performance also noting a final performance improvement, confirmed by data collected during the competitions too.

In conclusion, the study was useful for the purpose even if it is necessary to refine the assessment tools and adapting them to training plans. It's possible to anticipate an improvement of this system by adding tests to monitor the fundamental of "defence" and the fundamental of the "block".

\section{REFERENCES}

Alminni, C., Altavilla, G., Cassese, F.P., Ceciliani, A., D'isanto, T. (2019b) Physical and motor tests to estimate the improvement of the float serve, Journal of Human Sport and Exercise, 14 (Proc2), pp. S245-S250. https://doi.org/10.14198/jhse.2019.14.proc2.13

Altavilla, G., Gaetano, R. (2018). Physiological effects of warm-up and problems related to team sports, Sport Science, 11, 83-88.

D'Isanto, T., D'Elia, F., Raiola, G., Altavilla, G. (2019). Assessment of sport performance: Theoretical aspects and practical indications, Sport Mont, 17 (1):79-82. 
D'Isanto, T., Altavilla, G., Raiola, G. (2017). Teaching method in volleyball service: Intensive and extensive tools in cognitive and ecological approach. Journal of Physical Education and Sport, 17(S5): 2222-2227.

Di Tore, A.P., Raiola, G., D'Isanto, T. (2018). Situation awareness in sports science: Beyond the cognitive paradigm. Sport Science, 11 (1):44-48.

Federici, A., Zumbo, F., Raiola, G. (2019). Use of chains as a means of intensifying the load in resistance training, Journal of Physical Education and Sport, 19(68):466-472.

Forte, D., Ceciliani, A., Izzo, R., Altavilla, G. (2019a). Transition period: Pilot study on performance reduction of ability to jump in volleyball, Journal of Human Sport and Exercise, 14 (Proc2): S221S227. https://doi.org/10.14198/ihse.2019.14.proc2.09

Forte, D., Ceciliani, A., Izzo, R., Altavilla, G. (2019b) Transition period: Pilot study on performance reduction of ability to jump in volleyball, Journal of Human Sport and Exercise, 14 (Proc2), pp. S221S227. https://doi.org/10.14198/jhse.2019.14.proc2.09

Ferrara, F., Izzo, R., Ceciliani, A., Di Tore, A.P. (2019) Pilot study on the testing of Power Glove applied to volleyball, Journal of Human Sport and Exercise, 14 (Proc2), pp. S233-S238. https://doi.org/10.14198/ihse.2019.14.proc2.11

Invernizzi, P.L., Crotti, M., Bosio, A., Cavaggioni, L., Alberti, G., Scurati, R. (2019) Multi-teaching styles approach and active reflection: Effectiveness in improving fitness level, motor competence, enjoyment, amount of physical activity, and effects on the perception of physical education lessons in primary school children, Sustainability (Switzerland), 11 (2). https://doi.org/10.3390/su11020405

Izzo, R., Sopranzetti, S., Hosseini Varde'I, C., Molitierno, G. (2018). Video tracking for the detection of external load to establish proper parameters in elite soccer players during high intensity training, Journal of Physical Education and Sport, 18(178):1199-1202.

Parisi, F., Raiola, G. (2014). Video analysis in youth volleyball team, Journal of Human Sport and Exercise, 9, S584-S587. https://doi.org/10.14198/ihse.2014.9.proc1.50

Raiola, G., Parisi, F., Giugno, Y., Di Tore, P.A. (2013). Video analysis applied to volleyball didactics to improve sport skills, Journal of Human Sport and Exercise, 8 (2 SUPPL): 307-313. https://doi.org/10.4100/jhse.2012.8.proc2.33

Raiola, G. (2014). Teaching method in young female team of volleyball, Journal of Physical Education and Sport, 14 (1): 74-78.

\section{(9) $(\mathbb{\Theta \Theta}$}

This work is licensed under a Attribution-NonCommercial-NoDerivatives 4.0 International (CC BY-NC-ND 4.0). 